\title{
НЕДООЦЕНИВАЯ ВОЙНУ: ВЕЛИКИЕ ДЕРЖАВЫ В АСИММЕТРИЧНЫХ КОНФЛИКТАХ
}

Deriglazova Larisa. Great Powers, Small Wars: Asymmetric Conflict since 1945. Washington D.C.: Woodrow Wilson Press Center, Baltimore: Johns Hopkins University Press, 2Ø14. 384 p.

Дериглазова Л.В. Великие державы и малые войны: асимметричный конфликт после 1945 года. Вацингтон: издательство «Центра Вудро Вильсона», Балтимор: издательство Университета Джона Гопкинса, 2014. 384 с.

Книга профессора Томского государственного университета Ларисы Валерьевны Дериглазовой «Великие державы и малые войны: асимметричный конфликт после 1945 года», вышедшая на английском языке, стала итогом продолжительной исследовательской работы. Она способствовала отражению в международном профессиональном дискурсе российского взгляда на актуальную тематику вооружённого противостояния государств, существенно различающихся по своим материальным возможностям. Согласно оценке американского исследователя Айвана Арегин-Тофта [Arreguin-Toft 2005: 3-4], в конфликтах сильных государств с более слабыми оппонентами в 1950-1999 годах первые одерживали победу только в 48,8\% случаев. В этой связи научный анализ, подкреплённый примерами асимметричных вооружённых конфликтов с участием великих держав в новейшее время, представляется весьма значимым.

Несмотря на то что асимметричные по природе и методам ведения конфликты имели место на протяжении всей истории, внимание к их теоретическому осмыслению возросло во второй половине XX века. С одной стороны, это было связано с участившимися примерами вооружённого противостояния между мощными в воен- ном отношении державами и более слабыми игроками, появившимися в результате подъёма национально-освободительных движений и распада колониальных империй. Победа слабого противника над превосходящим с военной, экономической, идеологической и политической сторон оппонентом требовала объяснения. С другой стороны, противостояние между двумя блоками в условиях ракетно-ядерного пата заставляло СССР и США выводить «горячие фазы» вооружённой борьбы на периферию глобальной системы международных отношений, прибегая к опосредованным войнам. Изучение логики развития асимметричного конфликта несло практический смысл для военно-политического планирования и реализации конкретных внешнеполитических задач обеих сверхдержав.

Термин «асимметричный конфликт» был введён американским исследователем Эндрю Маком [Mack 1975: 175] в 1975 году. В работе «Почему большие нации проигрывают малые войны: политика асимметричного конфликта» он рассмотрел причины поражения США во Вьетнаме. Э. Мак одним из первых указал, что большие государства проигрывают заведомо более слабым противникам, поскольку теряют политическую волю к продолжению борьбы. Они оказываются неготовыми, в отличие 
от своих оппонентов, к противостоянию до конца, к длительным военным столкновениям в условиях партизанской войны. Они также подвержены влиянию внутренних факторов, воздействующих на их внешнюю политику.

С 1992 г. термин «асимметричные действия» появился в стратегических документах Вооружённых сил США при описании методов боевых действий, использующих сравнительное преимущество в силах над противником в местах концентрации его сравнительных уязвимостей, лишающих его тактического и стратегического превосходства (с. 24). В 2000-х годах термин «асимметричный» используется в документах Пентагона и Объединенного Комитета начальников штабов (ОКНШ) в качестве характеристики контрповстанческих иррегулярных боевых действий с негосударственными игроками.

В монографии Л.В. Дериглазовой приводится обширная историография рассматриваемой проблемы, включающая в себя анализ работ как классиков, так и современных исследователей (Раймона Арона, Майкла Фишеркеллера, Уильяма Зартмана, Кристофера Митчела, Гила Мерома, Адама Лаутера). Отечественные разработки проблемы асимметричного конфликта представлены в этом обзоре публикациями Е.А. Степановой, в которых основным предметом исследования выступает феномен политического терроризма. Для последнего асимметрия есть инструмент в борьбе с национальными государствами.

В контексте уже опубликованных работ целью монографии Л.В. Дериглазовой стало построение теоретической модели асимметричного конфликта на основе обширного исторического материала. Каждый конфликт имеет свою логику развития, однако сравнение совокупности разных по времени, масштабам и природе конфликтов позволяет выделить общие критерии сопоставления и выдвинуть гипотезы относительно причин поражения сильных держав. Теория асимметричных конфликтов решает задачи определения факторов, определяющих победу или поражение государств. Поражение сильной стороны конфликта можно объяснить политическим нежеланием продолжать борьбу, что, в свою очередь, обусловлено совокупностью причин.

В первую очередь, сказывается отсутствие очевидной военной победы над слабым противником, что обусловливается затяжными боевыми действиями и продолжающимися потерями, тактикой партизанских действий и террористических актов противоборствующей стороны, а также военной помощью слабой стороне извне со стороны недружественных государств. Способность великой державы проецировать силу также ограничивает рост негативного общественного отношения к войне. Оно приводит к потере легитимности войны при оценке смысловой связки «цели - результаты» (в этом контексте важна роль СМИ и возможности противоборствующих сторон влиять/управлять информационными потоками из зоны конфликта). Политику сильного государства затрудняют раскол или существенные разногласия в политической элите. Подобные проблемы важны и для демократических стран с их электоральными циклами, и для авторитарных правительств, поскольку поражение в войне от слабого противника может привести к корректировке или неконтролируемым изменениям режима. Среди других параметров, негативно влияющих на мотивацию сильных игроков, выступает увеличение экономических издержек и усиление негативного отношения к войне в международном сообществе.

Сложности в прогнозировании исхода асимметричного конфликта, а также в выработке тактики и стратегии сильной стороны определяются невозможностью симметричного сравнения ресурсов и выявления возможного образа действий слабой стороны в грядущем противоборстве. Итоги исторического анализа проигранных сильными государствами войн говорят о недооценке слабых оппонентов и невозможности перестроить тактику в ходе противостояния. При этом эволюция теоретической модели асимметричного конфликта 
привела к её усложнению, необходимости рассматривать противостояние не только в его военном аспекте.

В рамках эмпирических разработок Л.В. Дериглазовой методологическую сложность составляло выявление конфликта с признаками асимметричности для последующего анализа и определения причинно-следственных связей победы и поражения в них. Для этого автор рассматривала структурные характеристики участников конфликта (статус, ресурсы и возможности их использования, военно-политическая, социально-экономическая ситуация, при которой возникло противостояние, реакция международного сообщества) и их динамические характеристики (тактика и стратегия ведения противоборства, его продолжительность, интенсивность, изменение мотивации сторон).

Эмпирические данные для апробации теории были получены из двух крупных баз данных по конфликтам. Во-первых, база данных вооружённых конфликтов, составленная Университетом Упсала (Uppsala Conflict Data Program - UCDP) совместно с Международным институтом исследований проблем мира в Осло (PRIO). Во-вторых, база данных международных конфликтов COSIMO, составленная в Хайделбергском университете (ФРГ) под руководством профессора Франка Пфетча. База данных $U C D P$ содержит структурированную информацию (по 25 характеристикам) по 251 вооружённому конфликту с 1946 по 2006 год. База данных COSIMO классифицирует 692 международных конфликта, которые включают противостояния с использованием вооружённой силы также по 25 характеристикам за период 1945-1999 годов.

В монографии рассматривается логика построения обеих баз данных, сходства и различия в их методологии. Работа с ними даёт возможность оценивать «конфликтную» активность великих держав после окончания Второй мировой войны в хронологической последовательности, анализировать различные параметры конфликтов (прямая/косвенная вовлечённость, количество жертв, продолжительность, вмешательство третьих стран). По мнению Л.В. Дериглазовой, несмотря на широкие возможности, которые предоставляют базы данных, для точного выявления асимметричных конфликтов и более полного понимания причин поражения великих держав требуется предметное изучение каждого случая с учётом всех факторов, влияющих на их исход (с. 82).

В качестве иллюстраций для рассмотрения теории асимметричного конфликта исследователь выбрала два сюжета - распад Британской империи и война США в Ираке 2003-2011 годов. Каждому кейсу посвящено по главе монографии, в которой содержится изложение исторических событий и их анализ с опорой на заданную теоретическую рамку. Выбор этих примеров в качестве материала для апробации научного инструментария анализа асимметричных конфликтов связан с тем, что оба события, несмотря на имеющиеся различия, дают богатый материал для работы. Вместе с тем стоит отметить излишнее внимание автора к деталям описываемых кейсов, которое не всегда помогает достижению целей исследования и перегружает содержание книги.

Всесторонний анализ распада Британской империи, вооружённых конфликтов метрополии на зависимых территориях и их влияния на формирование будущего Британского Содружества - задача нетривиальная и амбициозная. Данный исторический процесс растянулся более чем на сто лет (с 1867 года, когда статус доминиона был предоставлен Канаде, до 1997 - передача КНР суверенитета над Гонконгом), наполненные как мирными эпизодами передачи власти, так и вооружёнными столкновениями [Carrington 1962: 29-39]. В этом смысле распад Британской империи как исторический сюжет даёт широкое пространство для анализа.

В период 1945-1982 годов Великобритания задействовала свои вооружённые силы в противостояниях на 28 зависимых территориях (с. 130-132). Не проходило и года, чтобы британские военные не использовались в боевых или гуманитарных 
миссиях. При этом Лондону удалось избежать долговременного противостояния в бывших колониях, сравнимого с кровопролитными французскими кампаниями в Индокитае и Алжире. Исключением могут считаться боевые действия в Малайе, где с 1948 г. велась борьба с партизанским движением, развёрнутым местной коммунистической партией. Противоборство закончилось объявлением независимости страны в 1957 году, но Лондон сохранил военно-политическое и экономическое влияние на неё (с. 138-140).

При этом Великобритания не прибегала к военным акциям в наиболее горячих точках колониальной империи (таких, как Палестина или индо-пакистанская граница). Поддержание военного превосходства по всей колониальной периферии требовало ресурсов и консенсуса по этому вопросу внутри британского общества. При их отсутствии конфликты, которые могли привести к кровопролитной борьбе между Великобританией и силами национально-освободительного движения, были урегулированы политическими способами с последующей передачей контроля над освобождавшимися странами США. Трезвая оценка рисков втягивания в асимметричные конфликты на периферии миросистемы для экономического и политического состояния страны в условиях начавшейся «холодной войны» позволила Лондону не только избежать больших потерь, но и сохранить во многих из них собственное влияние.

Второй пример анализа современной войны с позиции теории асимметричного конфликта, используемый автором в монографии, - война США в Ираке 20032011 годов. Неудачи американской военной операции в данном случае вполне объяснимы с точки зрения теории. В ходе исследования конфликт был разбит на фазы, которые автор проанализировала с точки зрения меняющихся политических и военных целей Вооруженных сил США. Эволюция противостояния приводила к неоднократной необходимости пересмотра тактики и стратегии, а также постанов- ки новых политических целей участия американских военных в конфликте. Автор рассмотрела данные из различных источников о количестве жертв и стоимости войны. Согласно подсчетам иракских общественных организаций, в 2003-2011 годах погибло более 150 тыс. гражданских лиц и более 10 тыс. военнослужащих, а по данным Пентагона, потери Соединённых Штатов составили 4489 погибших и 32230 раненых (с. 227-229). Финансовые же затраты как на ведение боевых действий, так и на программы помощи и восстановления Ирака в годы войны составили 657 млрд долларов США (с. 230).

Большое внимание автор уделила динамике изменения общественного отношения к войне, как и мнения политических элит в рассматриваемый период. Война США в Ираке дала образец для оценки влияния современного общества на способность политического руководства продолжать вести борьбу и достигать поставленных целей. В работе использован статистический материал замеров уровня общественного мнения и публикаций СМИ в динамике с 2003 по 2012 год. Он иллюстрирует уменьшение со временем поддержки военных действий администрации Дж. Буша-мл. в Ираке. Отсутствие крупных терактов на территории США за время иракской кампании стало единственным аргументом, оставшимся у её сторонников (с. 260). Этот конфликт не только стоил больших жертв, финансовых и репутационных потерь для самих США, но и оказал деструктивное воздействие на ближневосточную подсистему международных отношений, заложив основы для новых вооружённых конфликтов в регионе. Как и когда-то война во Вьетнаме, иракская авантюра подтвердила главный постулат теории асимметричных конфликтов: военное превосходство не даёт гарантию победы.

Феномен асимметричного конфликта подрывает гипотезу о том, что победа в вооружённом конфликте основана на доминировании сильнейшего. Соответственно, и теория баланса сил в международных от- 
ношениях, согласно которой стабильность в мире держится на равновесии великих держав, уже не кажется такой релевантной. Данный феномен показывает возможности малых игроков международных отношений в противостоянии большим. Асимметричные войны демонстрируют усложнение взаимосвязей между участниками современной международной системы, увеличение взаимозависимостей между политическими, экономическими, идеологическими аспектами внутренней жизни государства с его внешней политикой. Важной интеллектуальной задачей экспертного сообще- ства выступает проведение объективной оценки существующих и прогнозирования будущих конфликтов, а также их влияния на стабильность глобального порядка. Асимметричный конфликт остаётся уравнением со многими переменными, которые трудно просчитать. Теоретическая модель анализа таких конфликтов, представленная в монографии профессора Л.В. Дериглазовой, даёт один из способов его понимания.

Максим Волков кандидат исторических наук

\section{Список литературы}

Arreguin-Toft I. How the Weak Win Wars: A Theory of Asymmetric Conflict. Cambridge: Cambridge University Press, 2005. P. 250.

Carrington C.E. Decolonization: The Last Stages // International Affairs. 1962. Vol. 38. No. 1. P. 29-40.

Mack A. Why Big Nations Lose Small Wars: The Politics of Asymmetric Conflict // World Politics. 1975. Vol. 27. No. 2. P. 175-200.

\section{References}

Arreguin-Toft I. [2005). How the Weak Win Wars: A Theory of Asymmetric Conflict. Cambridge: Cambridge University Press. P. 250.

Carrington C.E. (1962). Decolonization: The Last Stages. International Affairs. Vol. 38, No. 1. P. 29-40. Mack A. (1975). Why Big Nations Lose Small Wars: The Politics of Asymmetric Conflict. World Politics. Vol. 27. No. 2. P. 175-200. 